\title{
First record of the genus Heterotrissocladius (Chironomidae: Orthocladiinae) from the Neotropical region
}

\author{
Ladislav Hamerlík $k^{1,2^{*}}$ and Fabio Laurindo da Silva ${ }^{3}$ \\ ${ }^{1}$ Institute of Geological Sciences, Polish Academy of Sciences, Warsaw, Poland \\ ${ }^{2}$ Department of Biology and Ecology, Matej Bel University, Banská Bystrica, Slovakia \\ Email: ladislav.hamerlik@gmail.com \\ *Corresponding author
}

${ }^{3}$ Laboratory of Systematic and Biogeography of Insecta, Department of Zoology, Institute of Biosciences, University of São Paulo, São Paulo, Brazil.

Email: fabiologia@gmail.com

\begin{abstract}
Here we report the occurrence of Heterotrissocladius (Diptera: Chironomidae: Orthocladiinae) for the first time in Central America, as well as in the Neotropical region. The report is based on sub-fossil chironomid head capsules from surface sediments of a high elevation lake, Lago Magdalena, Guatemala.
\end{abstract}

\section{Introduction}

Central America is an area particularly interesting for ecological and biogeographical studies, since it represents a bridge between two main biogeographical realms, the Nearctic and the Neotropical regions. Recent years have seen increased activity regarding chironomid systematics in the Neotropical region (e.g. Oliveira et al. 2013, Trivinho-Strixino et al. 2013, 2015, Andersen and Pinho 2014, Silva et al. 2014a,b, Andersen et al. 2015, Silva and Wiedenbrug 2015, Siri et al. 2015, Parise and Pinho 2016, Silva and Oliveira 2016, Silva and Ferrington 2018). At the same time, paleolimnological research, i.e. study of lake sediments as environmental archives, in Central America and the Caribbean region remains fragmentary. Indeed, lake sediments can be a valuable source of information not only of past environmental changes, but also recent distribution of species, since the sediment accumulating in the deepest part of a lake represents the mixture of the biological community from different parts of the lake as well as accumulation of communities from different time periods. Sediment examination thus saves time usually spent sampling in various locations and dates (Frey 1976). While some organisms are not well-preserved in sediments, chironomid larvae remain in good condition due to their chitinized head capsules.

A recent investigation of sub-fossil Chironomidae from surface sediments of lakes in Guatemala yielded an orthoclad species that was not readily identifiable, suggesting that it was a species unrecorded in Central America. Further detailed examination of this material revealed that the species belongs to the genus Heterotrissocladius Spärck, more specifically to Heterotrissocladius marcidus-type (Brooks et al. 2007). Here we report the occurrence of Heterotrissocladius (Diptera: Chironomidae: Orthocladiinae) for the first time in Central America, as well as in the Neotropical region.

\section{Material and Methods}

Surface sediment samples were collected from Lake Magdalena, located at $15.5426{ }^{\circ} \mathrm{N}, 91.3956{ }^{\circ} \mathrm{W}$, in Huehuetenango Province, Guatemala, on September 18, 2013. Magdalena is a small, shallow and high altitude lake (approximately 2,800 m a.s.1.), mostly surrounded by coniferous cloud forest composed almost exclusively of Guatemala fir with a few scattered pines and a thick ground cover of moss. Prior to sampling, the following physical and chemical parameters of the surface water were recorded: max. depth $2.8 \mathrm{~m}$, Secchi depth $2.8 \mathrm{~m}$, surface water temperature $12.5^{\circ} \mathrm{C}, \mathrm{pH} 8.8$, conductivity $331 \mu \mathrm{S} \mathrm{m}^{-1}$ and $\mathrm{O}_{2}$ content $6.2 \mathrm{mg}$ $\mathrm{L}^{-1}$ (for more details see Wojewódka et al. 2016).

Ekman grab sediment samples were taken from the deepest part and the littoral zone of the lake. Sediment samples were placed in plastic bottles $(100 \mathrm{~mL})$ immediately after collection, and stored under refrigeration. Extraction of head capsules from sediment samples followed the methodology described by Walker and Paterson (1985). Samples were deflocculated in 10\% KOH overnight without heating and subsequently passed through a $90 \mu \mathrm{m}$ mesh sieve. Chironomid head capsules were removed under a stereomicroscope and slide-mounted in Berlese mounting media. Identification followed Brooks et al. (2007) and Andersen et al. (2013). 


\section{Results and Discussion}

The littoral surface sediment sample yielded 97 chironomid remains, four of which were tentatively identified as Heterotrissocladius marcidus-type (sensu Brooks et al. 2007) (Fig. 1). The genus belongs to the subfamily Orthocladiinae and was erected by Spärck (1923) based on descriptions of adults of Metriocnemus cubitalis Kieffer, a junior synonym of Chironomus marcidus Walker, which has been carried as Heterotrissocladius marcidus (Walker). The genus contains more than 20 species (Ashe and O'Connor 2012) and is subdivided into three species groups: subpilosus, maeaeri and marcidus. Stur and Wiedenbrug (2005) reported additional, undescribed, Heterotrissocladius species in the Zoologische Staatssammlung München, which may indicate an additional species group in this genus.

Heterotrissocladius is closely related to Paratrissocladius, having similar larval antenna. However, Heterotrissocladius possesses 5 pairs of lateral teeth on mentum, wide ventromentral plates, bifid premandible, plumose SI and weak, serrate spines on pecten epipharyngis (Andersen et al. 2013), which guarantee its distinction.

The species within Heterotrissocladius are predominantly Holarctic in distribution and are often found in lakes (littoral to profundal), ponds, puddles, and in all sizes of flowing waters (Andersen et al. 2013). Larvae of the most widespread species of the genus, H. marcidus, occur throughout Europe (Spies and Sæther 2013) and North America (Epler 2001), and are also among the most common insects in alpine and subalpine lakes (Sæther 1975, Krno et al. 2006, Boggero et al. 2006, Bitušík et al. 2006, Füreder et al. 2006, Lods-Crozet et al. 2012). The four described paleo-morphotypes have different temperature optima, with $H$. marcidus-type being the least restricted to cold waters (Brooks et al. 2007).

The chironomid fauna of Central America includes multiple genera with worldwide distributions, as well as genera that are primarily Holarctic or Neotropical (Epler 2017). The Neotropical genera are typically an extension of the warm adapted fauna of lowland South America (Watson and Heyn 1992). Within this group, genera such as Diplosmittia, Goeldichironomus, Labrundinia, Lipurometriocnemus, Pentaneura and Polypedilum (Asheum) possess a Pan-American distribution, having secondarily dispersed into the

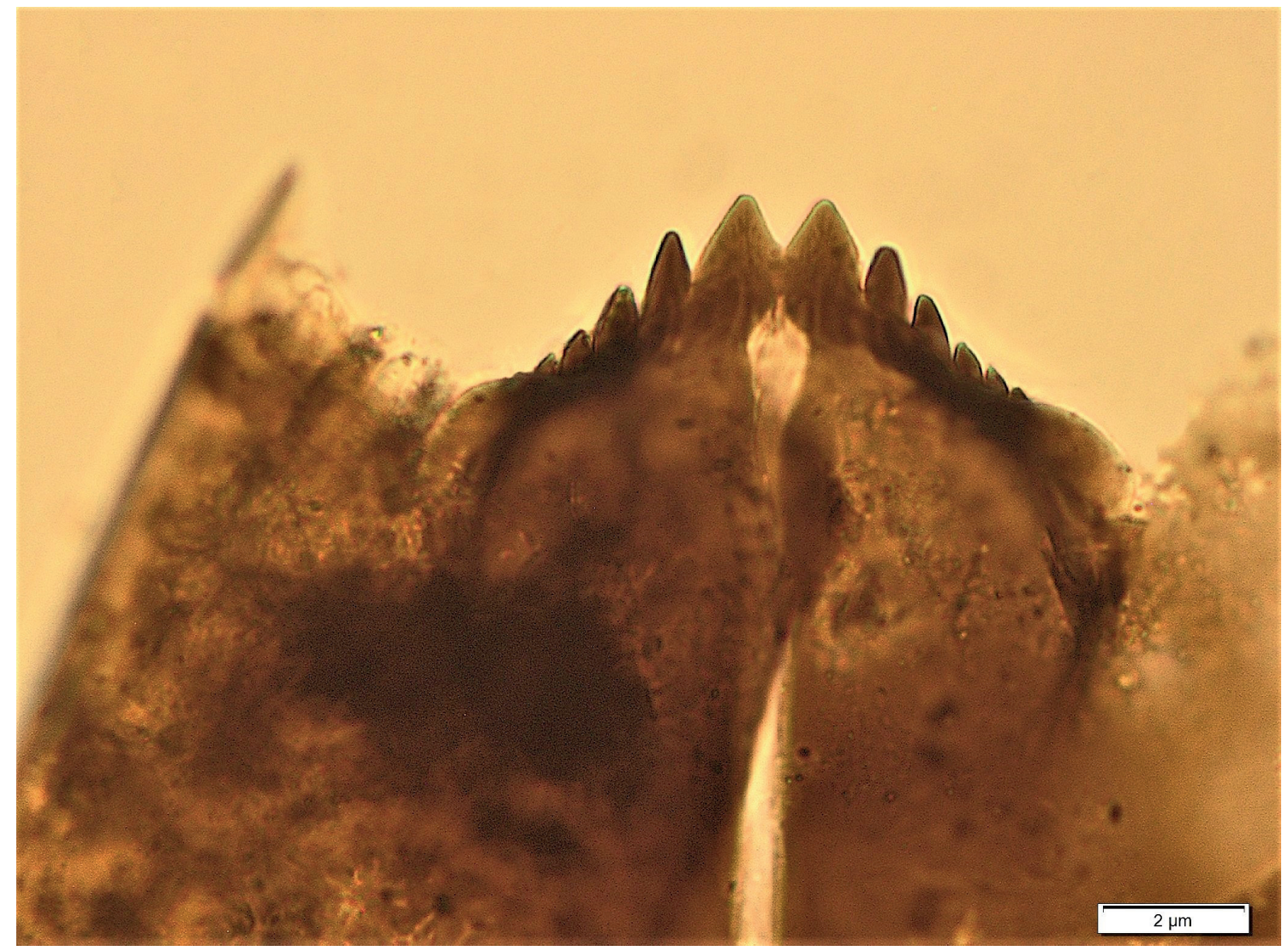

Figure 1. Head capsule of the subfossil Heterotrissocladius Spärck found in the surface sediment of the Lake Magdalena, Guatemala, autumn 2003. 
southern Nearctic via Central America or the Caribbean (Reiss and Sublette 1985). Other genera such as Heterotrissocladius and Orthocladius are most widespread in the Holarctic region (Silva et al. 2015). This first-report of a widespread genus in the Neotropical region highlights the need of additional inventories in order to better comprehend the diversity patterns of the chironomid communities in Central America and in the Greater Antilles archipelago.

\section{Acknowledgements}

The study was funded by the National Science Centre, Poland, contract no. 2015/19/P/ST10/04048. This project has received funding from the European Union's Horizon 2020 research and innovation program under the Marie Skłodowska-Curie grant agreement No. 665778. FLS was supported by fellowships from the Coordination for the Improvement of Higher Education Personnel (CAPES - 2014/9239-13-8) and São Paulo Research Foundation (FAPESP - 2016/07039-8).

\section{References}

Andersen, T., Mendes, H.F. and Pinho, L.C. 2015. Mariambera, a new genus of Orthocladiinae from Brazil (Insecta: Diptera, Chironomidae). - Studies on Neotropical Fauna and Environment 50: 24-30. DOI: https://doi.org/10.1080/01650521.2014.991589

Andersen, T., Sæther, O.A., Cranston P.S. and Epler, J.H. 2013. The larvae of Orthocladiinae (Diptera: Chironomidae) of the Holarctic region - Keys and diagnoses. In Andersen, T., Cranston, P.S. and Epler, J.H. (Eds) Chironomidae of the Holarctic Region - Keys and diagnoses. Part 1. Larvae. - Insect Systematics \& Evolution, Supplement 66: 189-385.

Andersen, T. and Pinho, L.C. 2014. A new species of Saetherocryptus Andersen et Mendes, 2007 (Diptera: Chironomidae, Orthocladiinae) from the Amazon rainforest, Brazil. - Norwegian Journal of Entomology 61: 160-164.

Ashe, P. and O'Connor, J.P. 2012. A World Catalogue of Chironomidae (Diptera). Part 2. Orthocladiinae. Irish Biogeographical Society and National Museum of Ireland, Dublin. 968 pp.

Bitušík, P., Svitok, M., Kološta, P. and Hubková, M. 2006. Classification of the Tatra Mountain lakes (Slovakia) using chironomids (Diptera, Chironomidae). - Biologia, 61(18): 191-201. DOI: https://doi. org/10.2478/s11756-006-0131-8

Boggero A., Füreder L., Lencioni V., Simcic T., Thaler B., Ferrarese U., Lotter A.F. and Ettinger R. 2006. Littoral chironomid communities of alpine lakes in relation to environmental factors. - Hydrobiologia 562 (1): 145-165. DOI: https://doi.org/10.1007/s10750-005-1809-6

Brooks, S.J., Langdon P.G. and Heiri, O. 2007. The Identification and Use of Palaearctic Chironomidae Larvae in Palaeoecology. QRA Technical Guide No. 10. QRA. London, 276 pp.

Epler, J.H. 2001. Identification Manual for the Larval Chironomidae (Diptera) of North and South Carolina: A Guide to the Taxonomy of the Midges of the Southeastern United States, Including Florida. Special Publication SJ2001-SP13 North Carolina, Department of Environment and Natural Resources, Raleigh, NC, and St. Johns River Water Management District, Palatka, Florida, 526 pp.

Epler, J.H. 2017. An annotated preliminary list of the Chironomidae (Diptera) of Zurquí, Costa Rica. Chironomus Journal of Chironomidae Research 30: 4-18. DOI: https://doi.org/10.5324/cjcr.v0i30.2240

Frey, D.G. 1976. Interpretation of Quaternary paleolimnology from Cladocera and Midges and prognosis regarding usability of other organisms. - Canadian Jpournal of Zoology 54: 2208-2226.

Füreder, L., Ettinger, R., Boggero, A., Thaler, B. and Thies, H. 2006. Macroinvertebrate diversity in Alpine lakes: effect of altitude and catchment properties. - Hydrobiologia 562 (1): 123-144. DOI: https://doi. org/10.1007/s10750-005-1808-7

Krno, I., Šporka, F., Galas, J., Hamerlík, L., Zat’ovičová, Z. and Bitušík, P. 2006. Littoral benthic macroinvertebrates of mountain lakes in the Tatra Mountains (Slovakia, Poland). - Biologia 61 (Suppl. 18): S147-S166. DOI: https://doi.org/10.2478/s11756-006-0127-4

Lods-Crozet, B., Oertli, B. and Robinson, C.T. 2012. Long-term patterns of chironomid assemblages in a high elevation stream/lake network (Switzerland) Implications to global change. - Fauna Norvegica 31: 71-85. DOI: https://doi.org/10.5324/fn.v31i0.1361 
Oliveira, C.S.N., Silva, F.L. and Trivinho-Strixino, S. 2013. Thalassomyia gutae sp. n., a new marine chironomid (Chironomidae: Telmatogetoninae) from the Brazilian coast. - Zootaxa 3701: 589-595. DOI: http://dx.doi.org/10.11646/zootaxa.3701.5.4

Parise, A.G. and Pinho, L.C. 2016. A new species of Stenochironomus Kieffer, 1919 from the Atlantic Rainforest in southern Brazil (Diptera: Chironomidae). - Aquatic Insects 37: 1-7. DOI: https://doi.org/ $\underline{10.1080 / 01650424.2015 .1115078}$

Reiss, F. and Sublette, J.E. 1985. Beardius, new genus with notes on additional Pan-American taxa. - Spixiana, Supplement 11: 179-193.

Sæther, O.A. 1975. Nearctic and Palaearctic Heterotrissocladius (Diptera: Chironomidae). Bulletin (Fisheries Research Board of Canada), No. 193, Fisheries and Marine Service, 67 pp. ISSN: 0068-7537.

Silva, F.L. and Ferrington Jr., L.C. 2018. Systematics of the new world genus Pentaneura Phillipi (Diptera: Chironomidae: Tanypodinae): historical review, new species and phylogeny. - Zoologischer Anzeiger 271: 1-31. DOI: https://doi.org/10.1016/j.jcz.2017.11.010

Silva, F.L. and Oliveira, C.S. 2016. Tanypus urszulae, a new Tanypodinae (Diptera: Chironomidae) from the Neotropical Region. - Zootaxa 4178: 593-600. DOI: http://dx.doi.org/10.11646/zootaxa.4178.4.9

Silva, F.L., Oliveira, C.S.N. and Trivinho-Strixino, S. 2014a. Metapelopia corbii gen. n., sp. n., a new Tanypodinae (Diptera: Chironomidae) from the Neotropical Region. - Annales de Limnologie - International Journal of Limnology 50: 85-95. DOI: https://doi.org/10.1051/limn/2014002

Silva, F.L. and Wiedenbrug, S. 2015. Amazonimyia gigantae gen. n., sp. n., a new Tanypodinae (Diptera: Chironomidae) from the Neotropical Region. - Zootaxa 3947: 275-281.DOI: http://dx.doi.org/10.11646/ zootaxa.3947.2.9

Silva, F.L., Wiedenbrug, S. and Farrell, B. 2015. A Preliminary survey of the non-biting midges (Diptera: Chironomidae) of the Dominican Republic. - Chironomus Journal of Chironomidae Research 28: 12-

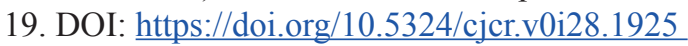

Silva, F.L., Wiedenbrug, S. and Oliveira, C.S.N. 2014b. Denopelopia moema, a new Tanypodinae (Diptera: Chironomidae) from the Neotropical Region. - Zootaxa 3753: 297-299. DOI: http://dx.doi.org/10.11646/ zootaxa.3753.3.9

Siri, A., Campos, R.E. and Donato, M. 2015. A new species of Larsia Fittkau, 1962 (Diptera: Chironomidae: Tanypodinae) from phytotelmata of Aechmea distichantha Lemaire, 1853 (Bromeliaceae) in Argentina. - Aquatic Insects 36: 125-134. DOI: https://doi.org/10.1080/01650424.2015.1045521

Spies, M. and Sæther, O.A. 2013. Fauna Europaea: Chironomidae. - In Pape, T. and Beuk, P, (Eds.): Fauna Europaea: Diptera, Nematocera. Fauna Europaea version 2018.08, http://www.faunaeur.org

Stur, E. and Wiedenbrug, S. 2005. Two new orthoclad species (Diptera: Chironomidae) from cold water springs of the Nationalpark Berchtesgaden, Germany. - Aquatic Insects, 27(2): 125- 131. DOI: https:// doi.org/10.1080/01650420400019817

Trivinho-Strixino, S., Silva, F.L. and Oliveira, C.S.N. 2013. Tapajos cristinae n. gen., n. sp. (Diptera: Chironomidae: Chironominae) from the Neotropical Region. - Zootaxa, 3710: 395-399. DOI: http://dx.doi. org/10.11646/zootaxa.3710.4.9

Trivinho-Strixino, S., Wiedenbrug, S. and Silva, F.L. 2015. New species of Tanytarsus van der Wulp (Diptera: Chironomidae: Tanytarsini) from Brazil. - European Journal of Environmental Sciences, 5: 92100. DOI: https://doi.org/10.14712/23361964.2015.82

Walker, I.R. and Paterson, C.G. 1985. Efficient separation of subfossil Chironomidae from lake sediments. - Hydrobiologia 122: 189-192. DOI: https://doi.org/10.1007/BF00032107

Watson, C.N. Jr. and Heyn, M.W. 1992. A preliminary survey of the Chironomidae (Diptera) Of Costa Rica, with emphasis on the lotic fauna. - Netherlands Journal of Aquatic Ecology 26(2-4): 257-262. DOI: https://doi.org/10.1007/BF02255249

Wojewódka, M., Zawisza, E., Cohuo, S., Macario-González, L., Schwalb, A., Zawiska, I. and Pérez, L. 2016. Ecology of Cladocera species from Central America based on subfossil assemblages. - Advances in Oceanography and Limnology 7(2): 145-156. DOI: https://doi.org/10.4081/aiol.2016.6266

Article submitted 2. July 2018, accepted by Alyssa M. Anderson 13. August 2018, published 28. August 2018. 